\title{
Synthesis, Biological Activities and Molecular Docking Studies of New Schiff Bases Derivatives
}

\author{
Yeni Schiff Bazlı Bileşiklerin Sentezi, Biyolojik Aktivite ve Moleküler Docking Çalışmaları
}

\author{
Dilek ÜNLÜER*1,a, Yasemin ÜNVER ${ }^{1, \mathrm{~b}}$, Ersan BEKTAŞ⿻̧, ${ }^{2, \mathrm{c}}$, Şahin DİREKEL ${ }^{3, \mathrm{~d}}$, Muhammet \\ KARAMAN $^{4, e}$, Halide Sedef KARAMAN ${ }^{5, f}$ \\ ${ }^{1}$ Department of Chemistry, Faculty of Science, Karadeniz Technical University, 61080, Trabzon, Turkey \\ ${ }^{2}$ Giresun University, Espiye Vocational School, 28600, Espiye, Giresun, Turkey \\ ${ }^{3}$ Department of Medical Microbiology, Faculty of Medicine, Giresun University, 28100 Giresun, Turkey \\ ${ }^{4}$ Department of Molecular Biology and Genetics, Faculty of Arts and Science, Kilis 7 Aralik University, 79000 Kilis, Turkey \\ ${ }^{5}$ Department of Chemistry, Faculty of Science, Ataturk University, 25240-Erzurum, Turkey
}

• Geliş tarihi / Received: 24.01.2020 • Düzeltilerek geliş tarihi / Received in revised form: 05.05.2020 • Kabul tarihi / Accepted: 01.06.2020

\begin{abstract}
In this study, new thiophene Schiff bases with morpholine $(1,2)$ were synthesized. The structures of the compounds were confirmed by ${ }^{1} \mathrm{H}-\mathrm{NMR},{ }^{13} \mathrm{C}-\mathrm{NMR}$ and IR spectrometry and their antioxidant, antibacterial, antileishmanial and enzyme activities were tested. The antioxidant activities observed from compounds 1 and 2 were remarkably high. According to the results obtained in our study, the compounds did not have antileishmanial activity (MIC >20000 $\mu \mathrm{g} / \mathrm{ml})$. It was determined that the synthesized compounds had different rates of antibacterial activity against nine different standard bacterial isolates. Enzyme inhibition effect of the compounds 1 and 2 was unimportant level and the compound exhibited low binding affinity against the enzyme in molecular docking studies. The compounds 1 and 2 formed many $\pi$ interactions with active site residue, however, they do not inhibit the enzyme due to did not interact with key residues of the enzymes. Our in silico and in vitro studies results were compatible with each other. As a result, the compounds 1 and 2 may be used as antioxidant and antimicrobial drugs, If they can be investigated as drug candidates.
\end{abstract}

Keywords: Antibacterial, Antileishmanial, Antioxidant, Enzym Activity, Morpholine, Schiff Base

$\ddot{O} z$

Bu çalışmada, morfolinli $(1,2)$ yeni tiyofen Schiff bazları sentezlenmistitir. Bileşiklerin yapıları, 1H-NMR, 13C-NMR ve IR spektrometrisi ile doğrulanarak antioksidan, antibakteriyel, antileishmanial ve enzim aktiviteleri test edilmistir. Bileşik 1 ve 2'den gözlemlenen antioksidan aktiviteler dikkat çekici derecede yüksek olarak belirlenmiştir. Çalışmamızda elde edilen sonuçlara göre, bileşikler antileishmanial aktivite göstermemiştir (MIC> $20000 \mu \mathrm{g} / \mathrm{ml}$ ). Sentezlenen bileşiklerin dokuz farklı standart bakteri izolatına karşı farklı antibakteriyel aktivite oranlarına sahip olduğu belirlenmişstir. Bileşik 1 ve 2'nin enzim inhibisyon etkisi önemsiz düzeyde olup ve bu bileșikler moleküler docking çalışmalarında enzimlere karşı düsük bağlanma afinitesi sergilemişlerdir. Bileşik 1 ve 2, aktif bölge kalıntısı ile birçok $\pi$ etkileşimi oluşturmuştur., Ancak, bu enzimlerin önemli kalıntıları ile etkileşime girmediği için enzimleri inhibe etmemişleridir. In siliko ve in vitro çalışma sonuçları birbiri ile uyumludur. Sonuç olarak bileşikler 1 ve 2, ilaç olarak araştırılırsa, antioksidan ve antimikrobiyal ilaçlar olarak kullanılabilir.

Anahtar kelimeler: Antibakteriyel, Antileishmanial, Antioksidan, Enzim Aktivitesi, Morfolin, Schiff Bazı

\footnotetext{
*a Dilek ÜNLÜER; dunluer@yahoo.com, Tel: (0546) 47753 61, orcid.org/0000-0003-1939-2246

${ }^{\mathrm{b}}$ orcid.org/0000-0001-5834-3223 $\quad{ }^{\mathrm{c}}$ orcid.org/0000-0001-9030-6908

${ }^{\mathrm{e}}$ orcid.org/0000-0002-0155-3223 $\quad{ }^{\mathrm{f}}$ orcid.org/0000-0001-7925-7156 


\section{Introduction}

Schiff bases have a broad spectrum of biological activities such as antibacterial, antioxidant, antiviral, antipyretic, anti-inflammatory, antifungal, anticancer, antiproliferative and antimalarial properties (Ünver et al. 2014, 2016, 2018). The compounds shown in Figure 1 are derived from natural products and contain Schiff base in their structure (Da Silva et al., 2011).
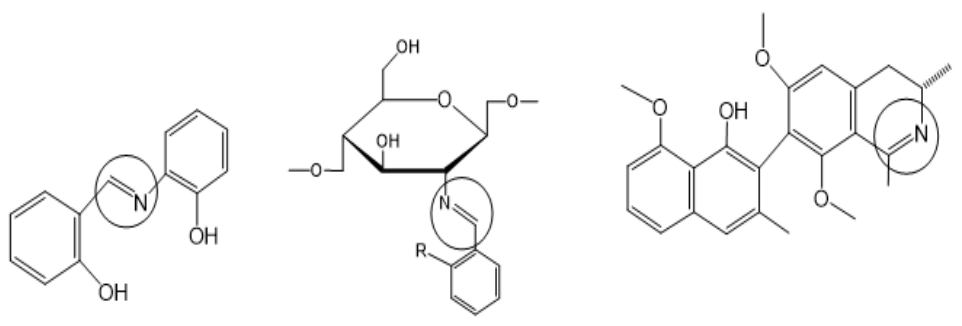

Figure 1. Bioactive Schiff base compounds

It is known that the antiepileptic drugs (AEDs) such as tiagabine, etizolam, brothizolam currently used contain Schiff base as well as thiophene as active pharmacophore group (Kulandasamy et al., 2009). In addition, Benzo [b] thiophene have antiinflammatory, analgesics, anti-fungal, antidepressant, anti-angiogenic, estrogen receptor modulating, anti-mitotic, enzyme inhibitors, anticancer, inhibiting kinases, anti-tuberculosis, anticonvulsant, anti-malaria, anti-hyperglycemic and pesticide activity (Bryant and Dere, 1998; Jagtap and Agasimundin, 2015; Jiang et al., 2003; Berrada et al., 2011).

Morpholine is known as a valuable structure for the synthesis of more efficacious antimicrobial agents. Especially, N-functionalized morpholines have found to possess diverse pharmacological activities such as antiemetic, antimicrobial, platelet aggregation inhibitory, proteinemic, anticancer, antihyperlipo, antitumor, antiproliferative, and bronchodilator activity (Aridos et al., 2007; Helal et al., 2013).

Glutathione reductase (GR) and glucose-6phosphate dehydrogenase (G6PD) enzymes play a key role in extinguishing of reactive oxygen species (ROS). Decreasing of their activity directly related ROS-induced diseases. (Berg et al., 2002). The enzymes are over-expressed, although ROS producing is high level in the cancer cell. Therefore, the enzymes' activity blocks oxidative stress (Kumari et al., 2018). Many researchers have focused on inhibiting the enzyme activity for cancer treatment by creating oxidative stress in the cancer cells.

In this study, we synthesized Schiff base derivatives containing thiophene with morpholine to obtain more effective biological activities.
Structures of synthesized compounds were characterized by IR, NMR, LC-MS/MS and 2. analysis. All compounds were evaluated in antioxidant, antibacterial, antileishmanial, enzym activities and in silico and in vitro studies.

\section{Experimental}

\subsection{General Information}

The ${ }^{1} \mathrm{H}$-, and ${ }^{13} \mathrm{C}$-Nuclear Magnetic Resonance spectra were recorded on a Bruker $400 \mathrm{MHz}$ spectrometer, where TMS as an internal standard and $\mathrm{DMSO}^{-\mathrm{d}_{6}}$ as solvent were used. IR spectra were recorded on a Perkin-Elmer Spectrum One FT-IR spectrometer in $\mathrm{KBr}$ pellets. The mass spectral analyses were carried out by a Micromass Quattro LC-MS/MS spectrometer. The elemental analyses were performed by Costech ECS 4010 instrument. Melting points were measured by an electrothermal apparatus.

\subsection{Synthesis of Schiff bases (1,2)}

4-morpholinoaniline $(0.01 \mathrm{~mol})$ and 5phenylthiophene-2-carbaldehyde / benzo[b] thiophene-2-carbaldehyde $(0.01 \mathrm{~mol})$ were heated for $1 \mathrm{~h}$. at $170-180{ }^{\circ} \mathrm{C}$. The reaction was controlled with TLC and the content cooled to room temperature. The obtained solid was recrystallized from a mixture of DMF and water. The synthesis of Schiff base derivatives with morpholine was performed following steps shown in the reaction Figure 2.

N-(4-morpholinophenyl)-1-(5-phenylthiophene2-yl)methanimine (1): Yield: $95.00 \%$. m.p: 227$229{ }^{\circ} \mathrm{C}$. IR $\left(\mathrm{KBr}, \mathrm{cm}^{-1}\right): 3072(\mathrm{CH}), 1609(\mathrm{C}=\mathrm{N})$, $1510(\mathrm{C}=\mathrm{C}) ;{ }^{1} \mathrm{H}$ NMR (400 MHz, DMSO-d 6 ) $\delta$ : $8.79(\mathrm{~s}, 1 \mathrm{H}, \mathrm{CH}=\mathrm{N}), 6.99-7.77(\mathrm{~m}, 11 \mathrm{H}$, arom $\mathrm{H})$, 
$3.75\left(\mathrm{~s}, 4 \mathrm{H}, \mathrm{O}-\mathrm{CH}_{2}\right), 3.15\left(\mathrm{~s}, 4 \mathrm{H}, \mathrm{N}-\mathrm{CH}_{2}\right) .{ }^{13} \mathrm{C}$ NMR (100 Hz, DMSO-d 6$) \quad \delta: 48.75,66.52$, $116.30,122.62,124.89,126.62,128.35,129.75$, $133.55,142.15,143.20,147.06,149.85,150.17$;
LC-MS (m/z): $349 \quad(\mathrm{M}+1,100 \%)$. Analysis (calculated/found) for $\mathrm{C}_{21} \mathrm{H}_{20} \mathrm{~N}_{2} \mathrm{SO}: \mathrm{C}: 72.38$ / 71.08, H: 5.79 / 4.65, N: 8.04/ 7.55.

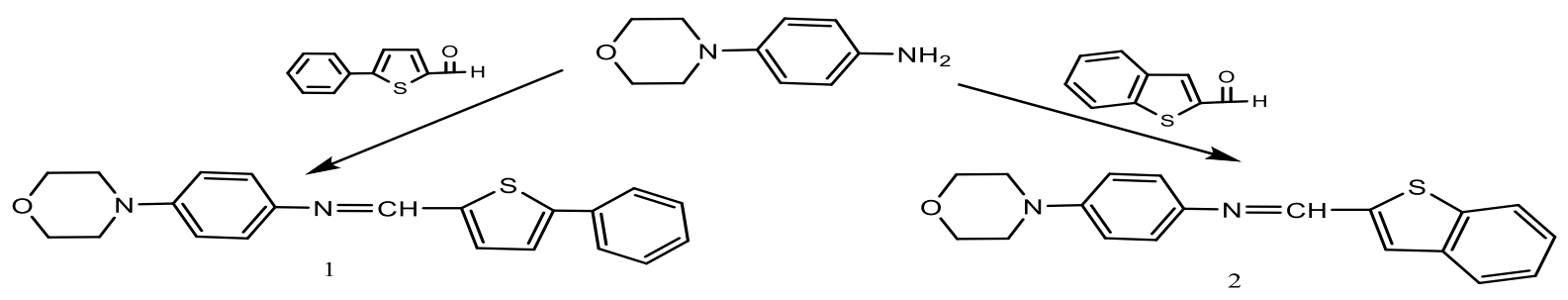

Figure 2. Synthetic pathway for the compounds 1-2.

1-(benzo[b]thiophene-2-yl)-N-(4morpholinophenyl)methanimine (2): Yield: 92.00\%. m.p: $284-286{ }^{\circ} \mathrm{C}$. IR $\left(\mathrm{KBr}, \mathrm{cm}^{-1}\right): 3058$ $(\mathrm{CH}), 1609(\mathrm{C}=\mathrm{N}), 1566(\mathrm{C}=\mathrm{C}) ;{ }^{1} \mathrm{H}$ NMR $(400$ MHz, DMSO-d 6 ) $\delta: 8.96(\mathrm{~s}, 1 \mathrm{H}, \mathrm{CH}=\mathrm{N}), 7.00-$ $8.11(\mathrm{~m}, 9 \mathrm{H}$, arom $\mathrm{H}), 3.75\left(\mathrm{~s}, 4 \mathrm{H}, \mathrm{O}-\mathrm{CH}_{2}\right), 3.16$ $\left(\mathrm{s}, 4 \mathrm{H}, \mathrm{N}-\mathrm{CH}_{2}\right) \cdot{ }^{13} \mathrm{C}$ NMR $\left(100 \mathrm{~Hz}, \mathrm{DMSO}-\mathrm{d}_{6}\right) \delta$ : $48.54,66.92,115.71,122.02,122.61,124.89$, $126.60,138.96,139.98,141.60,143.87,150.79$, 151.02; LC-MS (m/z): $323 \quad(\mathrm{M}+1,100 \%)$. Analysis (calculated / found) for $\mathrm{C}_{19} \mathrm{H}_{18} \mathrm{~N}_{2} \mathrm{SO}$ : C: 70.78 / 71.05, H: 5.63 / 6.50, N: 8.69/ 8.00.

In the FTIR spectra of compounds $\mathbf{1}$ and $\mathbf{2}, \mathrm{NH}_{2}$ and aldehyde signals belonging to starting compounds disappeared. In the ${ }^{1} \mathrm{H}$ NMR spectra of the compounds, proton signals belonging to imine group $\mathrm{N}=\mathrm{CH}$ of compounds $\mathbf{1}$ and $\mathbf{2}$ were observed at 8.79 and $8.96 \mathrm{ppm}$ respectively as singlet. In addition, imine $\mathrm{N}=\mathrm{CH}$ carbon signals were observed at 150.17 and $151.02 \mathrm{ppm}$ respectively in the ${ }^{13} \mathrm{C}-\mathrm{NMR}$ spectra. Further more, the other NMR data also supported structures of compounds $\mathbf{1}$ and $\mathbf{2}$. FTIR and NMR spectra of the compounds $\mathbf{1}$ and $\mathbf{2}$ were given in Supplemantry File.

\subsection{Antioxidant Activity}

\subsubsection{Method and Determination of Antioxidant Capacity}

The antioxidant activities of the compounds were analyzed by FRAP and DPPH tests, which are considered as a good indicator of the antioxidant capability of various compounds. The FRAP is an antioxidant activity determination method based on the reduction of $\mathrm{Fe}^{3+}$-TPTZ complex to the $\mathrm{Fe}^{2+}-$ TPTZ complex in the presence of antioxidants (Benzie et al., 1999). A volume of $100 \mu 1$ of the compound dissolved in DMSO was mixed with $3 \mathrm{~mL}$ of freshly prepared FRAP reagent. The reaction mixture was then incubated for $4 \mathrm{~min}$ at $37^{\circ} \mathrm{C}$. The absorbances of the substances were determined at $593 \mathrm{~nm}$ against the blank. A calibration curve was prepared using absorbances from the FeSO4.7H20 solution in the range of $31.25-1000 \mu \mathrm{M}$. FRAP values were stated as $\mu \mathrm{M} \mathrm{FeSO}{ }_{4} .7 \mathrm{H}_{2} \mathrm{O}$ equivalent/g sample.

The scavenging effects of the compounds against the 2,2-diphenyl-1-picrylhydrazyl (DPPH) radical were examined according to the method of Kartal et al., (2007) with some alterations. In the presence of an antioxidant, it is based on the decolorization of purple color of DPPH, and the change in absorbance is measured spectrophotometrically at $517 \mathrm{~nm}$. A volume of $0.75 \mathrm{~mL}$ of $0.1 \mathrm{mM}$ DPPH in methanol was mixed with an equal volume of dissolved compound solution in DMSO (at various concentrations), shaken well, kept in the dark for 50 minutes, and activity measured at $517 \mathrm{~nm}$ using Trolox as standard and values were revealed as $\mathrm{SC}_{50}(\mu \mathrm{g}$ sample per $\mathrm{mL}$ ).

\subsection{Antibacterial and Antileishmanial Activities}

\subsubsection{Preparation of Standard Bacterial Isolates}

In this study, it was aimed to evaluate the minimal inhibitory concentrations (MICs) of the synthesized compounds against nine different standard bacteria by the liquid microdilution method (CLSI) with alamar blue added. The standard obtained from the American Type Culture Collection (ATCC); Escherichia coli ATCC 25922, Yersinia enterocolitica ATCC 9610, Salmonella typhimurium ATCC 14028, Staphylococcus aureus (Methicillin Resistant; MRSA) ATCC 43300, Haemophilus influenzae ATCC 40247, Enterococcus faecalis ATCC 
29212 Shiels 25933 isolates were used. Standard bacteria were removed by removing the isolates from the freezer and waiting at room temperature. Bacteria were revitalized and purity checks were performed by incubating at $37^{\circ} \mathrm{C}$ overnight using bloody agar (Merck) and Eosin Methylene Blue Agar (EMB, Merck) media. Standard bacterial isolates were prepared in saline with an approximate number of bacteria of $1.5 \times 108 \mathrm{cfu} /$ $\mathrm{mL}$ according to McFarland 0.5 turbidity chart.

\subsubsection{Preparation of Leishmania infantum Promastigotes}

In the antiparasitic activity study, axenic standard MON-183 (Montpellier system) Leishmania infantum promastigot isolates were used. Standard isolates supplied are RPMI with 10\% Fetal Bovine Serum (FBS F4135 Sigma-Aldrich USA), $1 \%$ Penicillin (P3032 Sigma-Aldrich USA) and Streptomycin (S9137 Sigma-Aldrich USA) $(100,000$ units of penicillin and $10 \mathrm{mg}$ streptomycin). -1640 (Roswell Park Memorial Institute) (R8758 Sigma Aldrich USA) was reproduced in medium and passage was maintained.

Standard promastigote isolates were taken $20 \mathrm{ml}$ from the medium from which they were produced and transferred to sterile falcon tubes and centrifuged at $1.000 \mathrm{~g}$ for 10 minutes. Then, about $40 \mathrm{ml}$ of sterile Phosphate Buffered saline (PBS) was added to the promastigotes in the precipitate by discarding the supernatant in the tubes and vortexed at low speed. This prepared solution is $10 \mathrm{~min}$. It was centrifuged at $1.000 \mathrm{~g}$ and the procedure was repeated three times to wash the promastigots with PBS. Finally, promastigotes were diluted with RPMI-1640 to a cell count of $2.5 \times 107$ cells / $\mathrm{mL}$ using a hemocytometer.

\subsubsection{In Vitro Antibacterial Activity Test}

The synthesized compounds were dissolved in dimethyl sulfoxide (DMSO, Sigma de Aldrich, USA) / $\mathrm{H}_{2} \mathrm{O}(10 \%)$ and the final concentrations were diluted to $40 \mathrm{mg} / \mathrm{ml}$ with distilled water to prepare stock solutions. The stock solution of the compounds was sterilized by passing through sterile membrane filters with a diameter of 0.45 $\mu \mathrm{m}$. The antibacterial activity test of the stock solutions of the compounds was performed using 96-well sterile microplates. Firstly, $100 \mu 1$ of Mueller Hinton Broth (MHB, Merck) medium was added to all wells. As previously described (İskeleli et al., 2015), dilutions of the compounds were carried out in wells ranging from $20,000 \mu \mathrm{g} /$
$\mathrm{mL}$ to $625 \mu \mathrm{g} / \mathrm{mL}$. Then $100 \mu \mathrm{L}$ was added to each well from standard bacteria suspensions adjusted to McFarland 0.5 turbidity. Negative and positive control wells were prepared and the microplate was incubated in the incubator at $37^{\circ} \mathrm{C}$ for about 20 hours. After incubation, $20 \mu 1$ of alamar blue was added to all wells and incubated for again 4 hours. Microplates were evaluated visually after 24 and 48 hours. Color change into pink in the well after incubation was interpreted as positive bacterial growth, whereas blue color indicated absence of viability. In addition, growth control was performed by inoculation from each well to the blood agar medium. The antibacterial activity test for each compound was repeated twice, while amikacin was used as the control drug.

\subsubsection{In Vitro Antileishmanial Activity Test}

The synthesized compounds were dissolved in Dimethylsulfoxide (DMSO) / $\mathrm{H}_{2} \mathrm{O}(10 \%)$. Stock solutions of the compounds were prepared in a concentration of $40 \mathrm{mg} / \mathrm{mL}$ by addition of heatinactivated RPMI-1640 medium containing 10\% FBS and sterilized with a $0.45-\mu \mathrm{m}$ membrane filter. 96 well sterile microplates were used for antileishmanial activity testing. The Alamar blue added liquid microdilution method was performed as previously described (Süleymanoglu et al., 2017). The dilutions of the compounds in the wells were $20,000 \mu \mathrm{g} / \mathrm{mL}$ to $625 \mu \mathrm{g} / \mathrm{mL}$. $100 \mu \mathrm{l}$ of Leishmania infantum promastigotes were added to all wells. Negative and positive control wells were prepared and the microplate was incubated in the incubator at $27^{\circ} \mathrm{C}$ for about 20 hours in a cooled incubator. After incubation, $20 \mu \mathrm{l}$ of alamar blue was added to all wells and incubated for again 4 hours. Microplate was evaluated visually after 24,48 and 72 hours. Color change into pink in the well after incubation was interpreted as positive parasite growth, whereas blue color indicated absence of viability. In addition, $30 \mu \mathrm{l}$ samples were taken from all wells and fresh preparation was prepared for observing the vitality movements of the promastigotes in microscope and confirmed by the visual results. Amphotericin B was used as a standard control drug. The test was repeated twice for each compound.

\subsection{Enzyme Studies}

\subsubsection{Preparation of Blood Sample}

This study was approved by the Clinical Research Ethics Committee of Faculty of Medicine, 
Cukurova University, Adana, Turkey. The donor was informed consent that blood will collect by using a sterile syringe from their vein. Fresh human blood sample obtained from a healthy volunteer donor, 26 age male, in blood collection tube with EDTA. The sample was centrifuged for $15 \mathrm{~min}$ at $2500 \mathrm{~g}$, to collect red blood cell (RBCs). Collected RBCs were washed three times by centrifugation at $2500 \mathrm{~g}$ with serum physiological $(0.9 \% \mathrm{NaCl})$. For the hemolysis, RBCs are slowly vortexed with five volumes of ice-cold water, then centrifuged for $20 \mathrm{~min}$ at $10,000 \mathrm{~g}$ to remove the ghosts and intact cells. All studies were performed at $+4^{\circ} \mathrm{C}$.

\subsubsection{Ammonium Sulfate Precipitation}

Ammonium sulfate precipitation was carried 30$70 \%$ precipitation step for hGR enzyme (Erat et al., 2005) and 35-65\% precipitation step for hG6PD enzyme (Ninfali et al., 1990). The precipitate was obtained by centrifugation for 15 min at $5000 \mathrm{~g}$ and was immediately dissolved in ice-cold dialysis buffer $(50 \mathrm{mM} \mathrm{K}$-acetate $/ 50 \mathrm{mM}$ K-phosphate buffer, $\mathrm{pH}$ 7.0). The solution was dialyzed at against dialysis buffer for $2 \mathrm{~h}$ with two changes of buffer.

\subsection{3. hGR Purification}

In order to purify hGR enzyme, 2' 5 ' ADP Sepharose 4B (GE Healthcare Life Sciences, 717092-00 AF) which strongly interacts with $\mathrm{NADP}^{+}$-dependent dehydrogenases was used as affinity column resin. The column resin was equilibrated in binding buffer $(10 \mathrm{mM} \mathrm{K}$ phosphate, $0.15 \mathrm{M} \mathrm{NaCl}, \mathrm{pH}$ 7.3). The dialyzed proteins solution was loaded on the column. The resin was washed respectively with $25 \mathrm{~mL}$ of washing buffer $1(0.1 \mathrm{M} \mathrm{K}$-Ac, $0.1 \mathrm{M} \mathrm{K}$ phosphate, $\mathrm{pH} 6), 25 \mathrm{~mL}$ of washing buffer 2 (0.1 M K-Ac, 0.1 M K-phosphate, $\mathrm{pH}$ 7.85) and washing buffer $3(50 \mathrm{mM}$ K-phosphate, $1 \mathrm{mM}$ EDTA, pH 7) to cleaning non-binding enzymes on the column. Then Gr enzyme was eluted with 5 $\mathrm{mL}$ of step elution buffers (0-0.5 mM GSH and $0-1 \mathrm{mM}$ NADPH in $50 \mathrm{mM}$ potassium phosphate, 1 mM EDTA, pH 7) (Carlberg et al., 1981; Karaman et al., 2012). Elutes were collected at 1 $\mathrm{mL}$ volume in eppendorf tubes on ice. In all fractions, GR enzyme activity and protein amount were determined and active fractions were stored at $-80^{\circ} \mathrm{C}$ until performing kinetic studies by collecting. In the washing and eluting steps, the flow rates were $50 \mathrm{ml} \mathrm{h}^{-1}$ and $20 \mathrm{ml} \mathrm{h}^{-1}$, respectively.

\subsubsection{GR activity assay}

GR activity was measured from pure enzyme solution according to the method described by Carlberg and Mannervik (Carlberg et al., 1981) with Multiskan GO Spectrophotometer (Thermo Fisher Scientific Corporation) at $25^{\circ} \mathrm{C}$. Briefly, the optic density of mixture including $200 \mathrm{~mL}$ of $\mathrm{KH}_{2} \mathrm{PO}_{4} \quad(100 \mathrm{mM}), \quad 100 \mathrm{~mL}$ of oxidized glutathione (GSSG) $(20 \mathrm{mM})$ and $10 \mathrm{~mL}$ of pure enzyme solution was spectrophotometrically measured for $3 \mathrm{~min}$. at $340 \mathrm{~nm}$, following $100 \mathrm{~mL}$ of NADPH ( $2 \mathrm{mM})$ added. The measurement was repeated three times. The enzyme activity was calculated using a molar extinction coefficient of NADPH $\left(6.22 \mathrm{mM}^{-1} \mathrm{~cm}^{-1}\right)$ with equation (I). A unit of GR enzyme is defined as the amount of enzyme required to oxidase one mmol NADPH per minute.

\subsection{5.hG6PD Purification}

In order to purify hG6PD enzyme, 2'5' ADP Sepharose 4B (GE Healthcare Life Sciences, 717092-00 AF) which strongly interacts with $\mathrm{NADP}^{+}$-dependent dehydrogenases was used as affinity column resin. The column resin was equilibrated in binding buffer $(10 \mathrm{mM} \mathrm{K}$ phosphate, $0.15 \mathrm{M} \mathrm{NaCl}, \mathrm{pH}$ 7.3). The dialyzed proteins solution was loaded on the column. The resin was washed with washing buffer $(50 \mathrm{mM} \mathrm{K}$ phosphate, $1 \mathrm{mM}$ EDTA, $1 \mathrm{mM}$ dithiothreitol, 80 $\mathrm{mM} \mathrm{KCl}, \mathrm{pH}$ 7.35) to cleaning non-binding enzymes on the column. Then hG6PD enzyme was eluted with $20 \mathrm{~mL}$ of elution buffer $(80 \mathrm{mM}$ K-phosphate, $80 \mathrm{mM} \mathrm{KCl}, 0.5 \mathrm{mM} \mathrm{NADP}{ }^{+}$, 1 mM EDTA, pH 7.35). Elutes were collected at 1 $\mathrm{mL}$ volume in eppendorf tubes on ice. In all fractions, hG6PD enzyme activity and protein amount were determined and active fractions were stored at $-80^{\circ} \mathrm{C}$ until performing kinetic studies by collecting. In the washing and eluting steps, the flow rates were $50 \mathrm{ml} \mathrm{h}^{-1}$ and $20 \mathrm{ml} \mathrm{h}^{-1}$, respectively.

\subsection{6. hG6PD activity assay}

hG6PD enzyme activity was measured from pure enzyme solution according to the method described by Beutler (Beuther, 1975) with Multiskan GO Spectrophotometer (Thermo Fisher Scientific Corporation) at $25^{\circ} \mathrm{C}$. Briefly, the optic density of mixture including $200 \mathrm{~mL}$ of Tris- $\mathrm{HCl}$ $(50 \mathrm{mM}), 100 \mathrm{~mL}$ of glucose-6-phosphate (G6P) $(6 \mathrm{mM})$ and $10 \mathrm{~mL}$ of supernatant was spectrophotometrically measured for $3 \mathrm{~min}$. at 340 $\mathrm{nm}$, following $100 \mathrm{~mL}$ of $\mathrm{NADP}^{+}(2 \mathrm{mM})$ added. 
The measurement was repeated three times. The enzyme activity was calculated using a molar extinction coefficient of NADPH $\left(6.22 \mathrm{mM}^{-1} \mathrm{~cm}^{-1}\right)$ with equation (I). A unit of hG6PD enzyme is defined as the amount of enzyme required to reduce one mmol $\mathrm{NADP}^{+}$per minute.

$E U=\frac{\Delta_{\lambda 340}}{\varepsilon \times t \times l} \times \frac{V_{E}}{V_{T}} \times D F$

$\varepsilon$ : The extinction coefficient of NADPH, $6.22 \mathrm{mM}^{-1} \mathrm{~cm}^{-1}$; $\mathrm{t}$ : Time of reaction, minute; 1 : Beam path, $\mathrm{cm} ; \mathrm{V}_{\mathrm{E}}$ : Total enzyme volume; $\mathrm{V}_{\mathrm{T}}$ : Total cuvette volume; DF: Dilution factor

\subsubsection{Protein assay}

Protein concentrations were performed according to the method described by Bradford. A (Bradford, 1976) standard curve was generated with absorbance values of bovine serum albumins solutions at different concentrations.

\subsubsection{Kinetics Studies}

Effect of molecule $\mathbf{1}$ and $\mathbf{2}$ and DMSO on hGR and hG6PD enzyme activity were detected by using solution of the molecules and DMSO at different concentrations into the reaction cuvette. The enzymes activity was spectrophotometrically measured and measurement performed without molecules was used as a control.

\subsection{Molecular Docking Studies}

To gain some insight into the binding mechanism between molecules and human glutathione reductase and human glucose 6-phosphate dehydrogenase enzymes, molecular docking studies were performed using Small Drug Discovery Suites package (Schrödinger, Inc.).

\subsubsection{Ligand Preparation}

3D structures of molecules $\mathbf{1}$ and $\mathbf{2}$ were obtained by drawing 2D structures of the molecules. Correct molecular geometries of the 3D structures were generated using Epik module and correct protonation state at $\mathrm{pH} 7.0 \pm 2.0$ of the 3D structures was reached using OPLS-2005 force field (Bayrak et al., 2019; Turkan et al., 2019).

\subsubsection{Protein Preparation and Binding Site Detection}

The crystal structure of hGR and hG6PD receptors (PDB code 3DK9 and 6E08, respectively) were accessed from RCSB Protein Data Bank. Since they have the best percentile ranks than other enzymes, the crystal structures were chosen for use in molecular docking studies. Moreover, the crystal structures have a ligand in the active site. This situation provides an advantage in performing docking validation study.

The crystal structures were prepared using Protein preparation wizard panel. Protein workflows are briefly, as follows. In the first step, bond order and charges were assigned by using chemical component dictionary, missing hydrogen atoms were added to crystal structures, and then zero bond order to metals and disulphide bonds were created between two Sulphur atoms. Missing side chains were filled with the help of Prime module. In the second step, amino acids were ionized by setting pH 7.0 using Propka module and hydroxyl, Asn, Gln, and His residues were optimized using ProtAssign module. Water molecules that were formed less than 3 contacts with the protein or ligand were removed. In the last step, energy minimization and geometry optimization have also been performed using OPLC force field until RMSD was $0.30 \AA$ for heavy atoms (Turkan et al., 2019). Following protein preparation, binding site of prepared receptors was identified using SiteMap module. Binding sites were generated into the prepared receptors with default parameter of top-ranked potential protein binding sites setting. The toll also calculated Sitescore and Dscore of binding sites. The scores were used evaluating binding site of the receptors whether exhibit active site properties or not (Bayrak et al., 2019; Turkan et al., 2019).

\subsubsection{Binding Mechanism Detection}

In order to understand and explain binding mechanism between the molecules and the receptors, molecular docking studies were performed using Induced Fit Docking (IFD) module. Docking workflows are briefly, as follows. In the first step, Centroid of the residues was generated around ligand in the active site (Flavin adenine dinucleotide and nicotinamide adenine dinucleotide phosphate, respectively) of hGR and hG6PD receptors. In the second step, side chains were automatically trimmed based on B-factor and in the last step, closest residues to the ligand were refined within $3.4 \AA$ of ligand pose in prime refinement. In order to validate accuracy of the IFD process, ligands in the active site of the receptors were re-docked into active site of the receptors. Following docking validation, molecules $\mathbf{1}$ and $\mathbf{2}$ were docked into active sites of the hGR and hG6PD receptors by IFD 
methodology (Bayrak et al., 2019; Turkan et al., 2019).

\section{Results and Discussion}

\subsection{Antioxidant Activity}

In this study, FRAP and DPPH tests were followed to appraise the antioxidant activities of compounds 1 and 2 and the results are given in the Figure 3. In the FRAP and DPPH tests, the upgrade $\mathrm{FeSO}_{4} .7 \mathrm{H}_{2} \mathrm{O}$ equivalent and the decrescent $\mathrm{SC}_{50}$ rates are indicative of more powerful activity. When the results were compared with the results obtained from the standard antioxidant compound (Trolox and BHT), it was detected that the activities observed from compounds 1 and 2 were remarkably high. In the ferric reducing power test, the FRAP rates were identified as $1825.27 \mu \mathrm{M} \quad \mathrm{FeSO}_{4} .7 \mathrm{H}_{2} \mathrm{O}$ equivalent/g sample in compound 1 and 432.34 $\mu \mathrm{M} \quad \mathrm{FeSO}_{4} .7 \mathrm{H}_{2} \mathrm{O}$ equivalent/g sample in compound 2. In the DPPH assay, compounds 1 and 2 have a considerable free radical scavenging effect with $\mathrm{SC}_{50}$ values of 7.96 and $12.87 \mu \mathrm{g} / \mathrm{mL}$, respectively The $\mathrm{SC}_{50}$ values of standard antioxidant compounds, namely trolox and BHT were found as 29.58 and $92.31 \mu \mathrm{g} / \mathrm{mL}$, respectively.

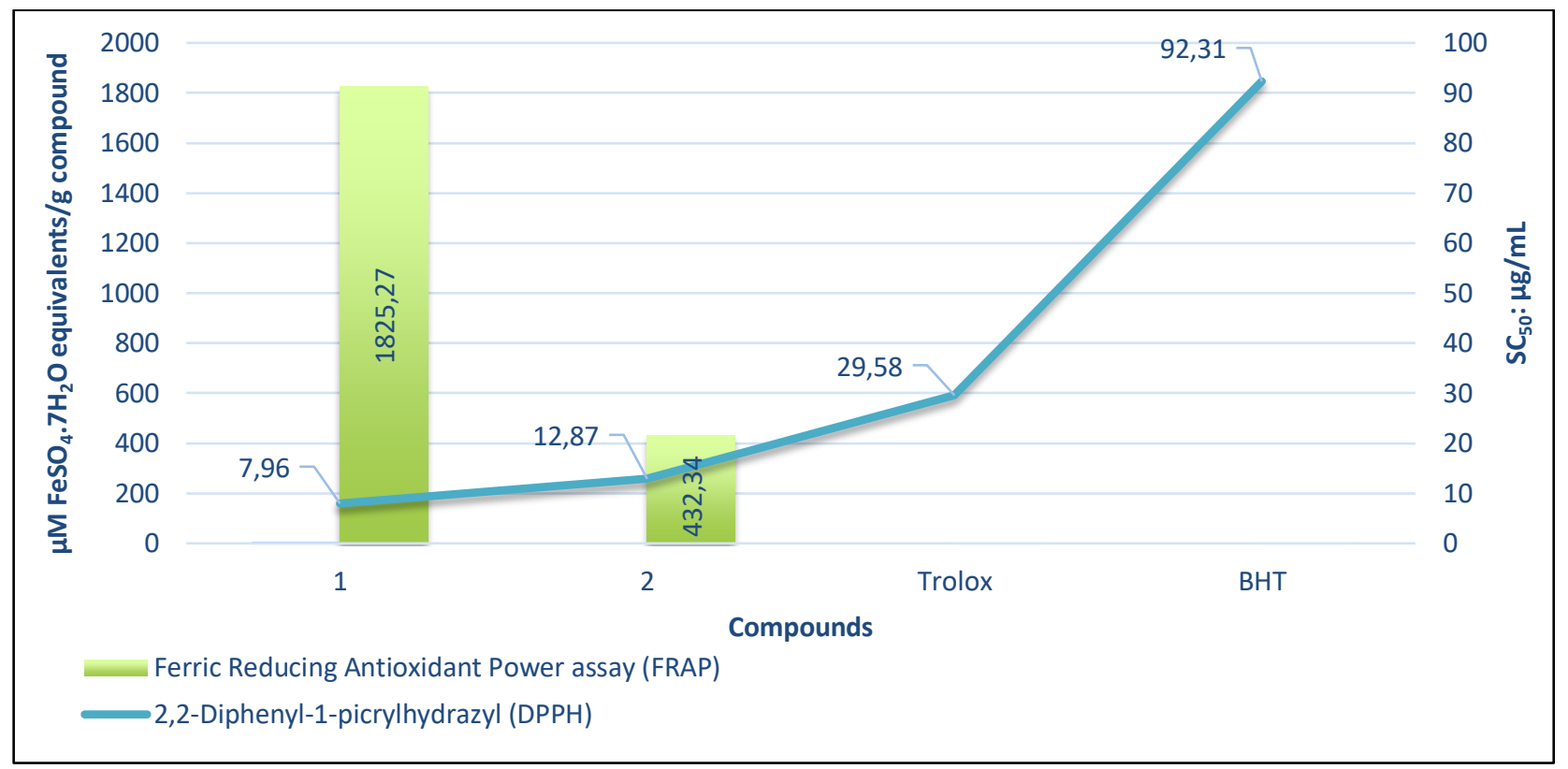

Figure 3. Ferric reducing antioxidant power (FRAP), and radical scavenging activities (DPPH) of compounds.

\subsection{Antileishmanial and Antibacterial Activities}

In this study, antileishmanial activity of the synthesized compounds was investigated by using liquid microdilution alamar blue method in 96well microplates. If the color changes from blue to pink the parasite continues to growth, the color does not change is interpreted as the parasite is not growth. The antileishmanial activity of the compounds is shown in Figure 4. In the study, the MIC values belong antileishmanial activity of the compounds were determined $>20000 \mu \mathrm{g} / \mathrm{mL}$ and are shown in Table 1. Visual results and microscopic examination results were found to be consistent with each other. The compounds did not show any antileishmanial activity at the studied concentrations.
Table 1. Minimal Inhibitory Concentration (MIC) value of the compounds against Leishmania infantum Promastigotes

\begin{tabular}{|l|l|l|}
\hline & & $\begin{array}{l}\text { MIC value } \\
(\mu \mathrm{g} / \mathrm{mL})\end{array}$ \\
\hline 1 & Compound 1 & $>20.000$ \\
\hline 2 & Compound 2 & $>20.000$ \\
\hline 3 & Amphotericin $\mathrm{B}$ & $<625$ \\
\hline
\end{tabular}

It was determined that the synthesized compounds had different rates of antibacterial activity against nine different standard bacterial isolates. Compound 1 was found to be ineffective (MIC $>20000(\mu \mathrm{g} / \mathrm{mL}))$ against the isolate of $P$. mirabilis while the most effective (MIC: $2500(\mu \mathrm{g} / \mathrm{mL})$ ) was against the $E$. coli isolate. 


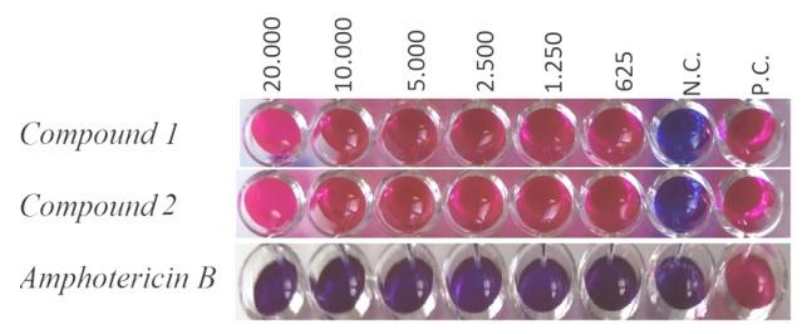

Figure 4. The result of antileishmanial activity against the standard Leishmania infantum promastigotes; N.C. Negative Control, P.C. Positive Control
Compound 2 was found to be ineffective (MIC $>20000(\mu \mathrm{g} / \mathrm{mL}))$ against $P$. mirabilis and $K$. pneumoniae isolates while the most effective (MIC: $2500(\mu \mathrm{g} / \mathrm{mL})$ ) was found against E. coli and $Y$. enterocolitica isolates. As expected in the study, the color of the positive control well changed from blue to pink, whereas no color change was observed in the negative control well. In this study, Minimal Inhibitor Concentration (MIC) values of the compounds are shown in Figure 5, 6 and Table 2.

Table 2. Results of antibacterial activity of compounds

\begin{tabular}{|c|c|c|c|c|c|c|c|c|c|}
\hline Bacteria & 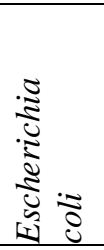 & 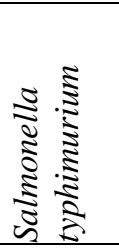 & 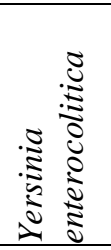 & 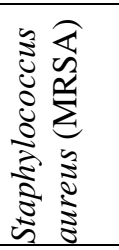 & 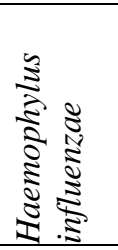 & 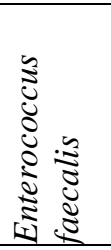 & 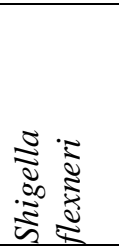 & 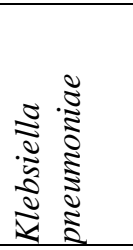 & 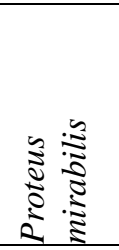 \\
\hline $\begin{array}{l}\text { Compound } 1 \\
(\mu \mathrm{g} / \mathrm{mL})\end{array}$ & 2500 & 20000 & 20000 & 10000 & 5000 & 5000 & 20000 & 20000 & $>20000$ \\
\hline $\begin{array}{l}\text { Compound } 2 \\
(\mu \mathrm{g} / \mathrm{mL})\end{array}$ & 2500 & 20000 & 2500 & 10000 & 10000 & 10000 & 20000 & $>20000$ & $>20000$ \\
\hline Amikacin & $<625$ & $<625$ & $<625$ & $<625$ & $<625$ & $<625$ & $<625$ & $<625$ & $<625$ \\
\hline
\end{tabular}

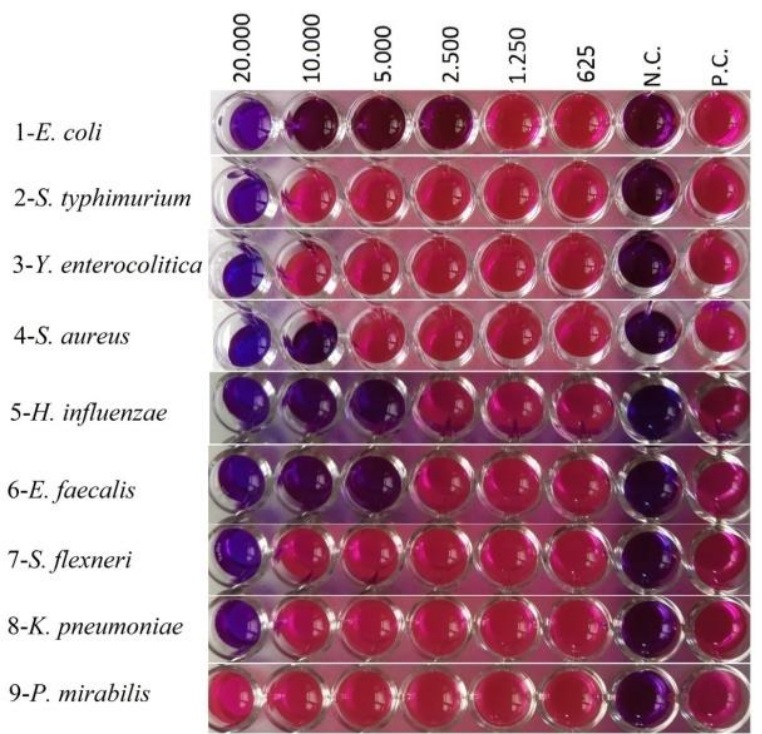

Figure 5. Results of antibacterial activity of Compound 1; 1- E. coli, 2-S. typhimurium, 3-Y. enterocolitica, 4- S. aureus, 5- H. influenzae, 6- $E$. faecalis, 7- S. flexneri, 8- K. pneumoniae, 9- P. Mirabilis

N.C. Negative Control, P.C. Positive Control

In our study, the antibacterial activities of the synthesized compounds against some bacteria (Escherichia coli, Salmonella typhimurium,
Methicillin Resistant Staphylococcus aureus) which cause foodborne diseases were tested. The tested compounds showed the best antibacterial activity against to Escherichia coli and Yersinia enterocolitica isolates.

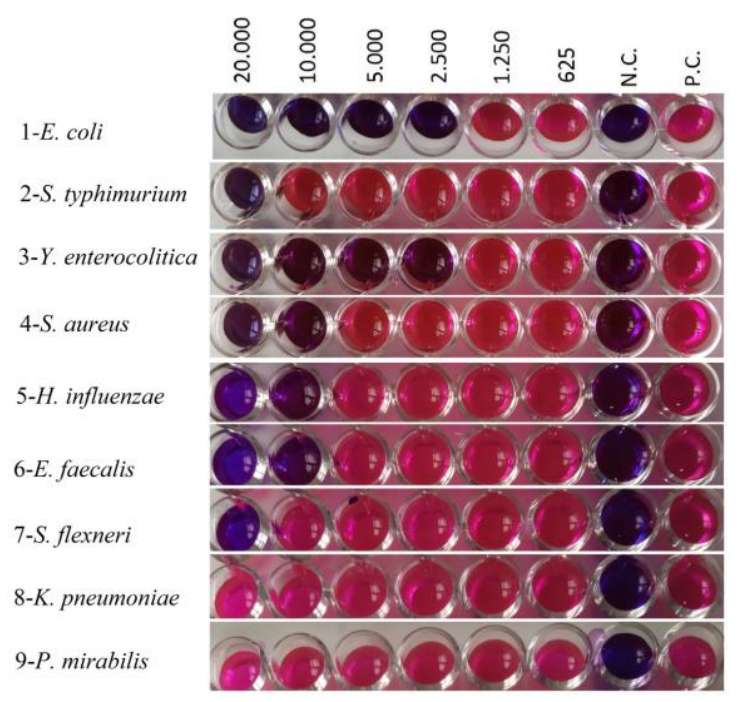

Figure 6. Results of antibacterial activity of Compound 2; 1- E. coli, 2- S. typhimurium, 3- $Y$. enterocolitica, 4- S. aureus, 5- H. influenzae, 6- E. faecalis, 7- S. flexneri, 8- K. pneumoniae, 9- P. Mirabilis

N.C. Negative Control, P.C. Positive Control 
The purpose of the control drug study was made to test whether the experimental study was working properly. The substances studied showed antibacterial activity even if they had a higher value than the MIC of the standard drug amikacin. In this antimicrobial activity study, while aiming to determine the concentration of the compound that is effective against bacteria, the reliability, toxic effect and side effects of the substances should also be evaluated for new drug candidates. In order to use the compounds evaluated for their antileishmanial and antibacterial activities as drug active substances, further studies are required: control studies in experimental animal models are needed in vivo.

No research has been conducted so far on antileishmanial activity of the compounds used in this study. According to the results obtained in our study, the compounds did not have antileishmanial activity (MIC $>20000 \mu \mathrm{g} / \mathrm{mL}$ ) (Table 1). Amphotericin B, which was used as a standard drug, was found to be effective even at the lowest concentration ( $\mathrm{MIC}=<625 \mu \mathrm{g} / \mathrm{mL}$ ).
Mikus et al. (Mikus et al., 2000) also showed that alamar blue was the applicable colorimetric indicator in the drug screening test with $L$. major promastigotes. In our study, alamar blue was used as indicator dye.

As a result; in this study, it was determined that the synthesized compounds has antibacterial activity against different bacteria while the antileishmanial activities were not found. For the use of synthesized compounds as a medicine; In vitro macrophage culture, which is thought to be necessary, has a need for efficacy against Leishmania amastigotes and control studies in experimental animal models in vivo.

\subsection{Enzyme Purification}

We purified hGR and hG6PD enzyme from human erythrocyte with 2',5' -ADP Sepharose-4B affinity chromatography. Purification scheme of purified enzymes has shown in Table 1 . As seen in Table 3, purified hGR and hG6PD enzymes have specific activity (SA) with 12.535 and 7.08, respectively. The enzymes purified with purification factor 10474 and 186, respectively.

Table 3. Purification scheme of hGR and hG6PD from human erythrocyte.

\begin{tabular}{|c|c|c|c|c|c|c|c|c|c|c|c|c|c|c|c|c|}
\hline \multirow[t]{2}{*}{ 莺 } & \multicolumn{2}{|c|}{ 忌氞 } & \multicolumn{2}{|c|}{ 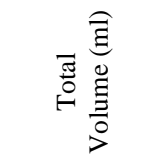 } & \multicolumn{2}{|c|}{ 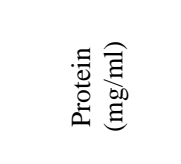 } & \multicolumn{2}{|c|}{ 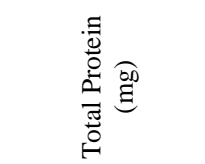 } & \multicolumn{2}{|c|}{ 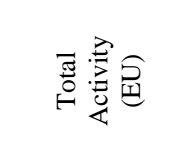 } & \multicolumn{2}{|c|}{ 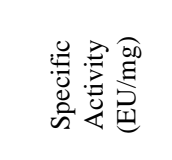 } & \multicolumn{2}{|c|}{$\stackrel{\overrightarrow{0}}{\stackrel{0}{0}}$} & \multicolumn{2}{|c|}{ 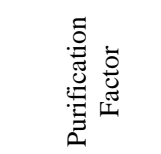 } \\
\hline & 兽 & 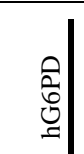 & $\underset{0}{\stackrel{0}{0}}$ & 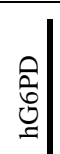 & $\underset{0}{\stackrel{0}{0}}$ & 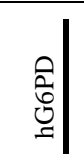 & 品 & $\begin{array}{l} \\
\\
0 \\
0 \\
0 \\
0 \\
\text { | }\end{array}$ & 孞 & 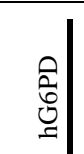 & 엉 & 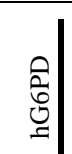 & 吕 & 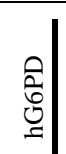 & 胥 & 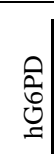 \\
\hline 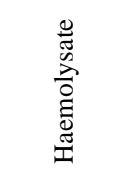 & 0.011 & 0.493 & 40 & 46 & 8.956 & 12.02 & 358.23 & 552.92 & 0.429 & 22.68 & 0.001 & 0.04 & 100 & 100 & 1 & 1 \\
\hline 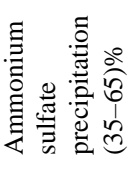 & 0.107 & 0.430 & 1.3 & 6 & 4.200 & 3.04 & 5.460 & 17.33 & 0.139 & 2.58 & 0.026 & 0.13 & 33 & 9 & 21 & 3 \\
\hline 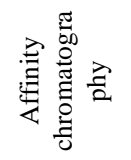 & 0.401 & 0.219 & 5 & 3 & 0.003 & 0.03 & 0.016 & 0.08 & 2.004 & 0.66 & 12.53 & 7.82 & 468 & 2 & 10474 & 186 \\
\hline
\end{tabular}

\subsection{Enzyme Kinetics}

Effect of the compounds on hGR and hG6PD enzymes was detected using different concentrations of the compounds. With the kinetic studies results, we carve out activity (\%) vs. compound concentration graph and presented it in Figure 7. $216 \mu \mathrm{M}$ of compound 1 and $232 \mu \mathrm{M}$ of compound 2 slightly inhibited both hGR and hG6PD enzyme. The compounds solve in 
dimethyl sulfoxide (DMSO), so the activity mixture with water could not be prepared at concentrations greater than the specified compound concentrations. Moreover, we examined the effects of DMSO on hGR and hG6PD enzymes we observed that DMSO inhibits enzymes more than compounds 1 and 2 at concentrations above $300 \mathrm{mM}$. When considering the effect of DMSO on the enzyme, inhibition effect of the compounds 1 and 2 is unimportant level.
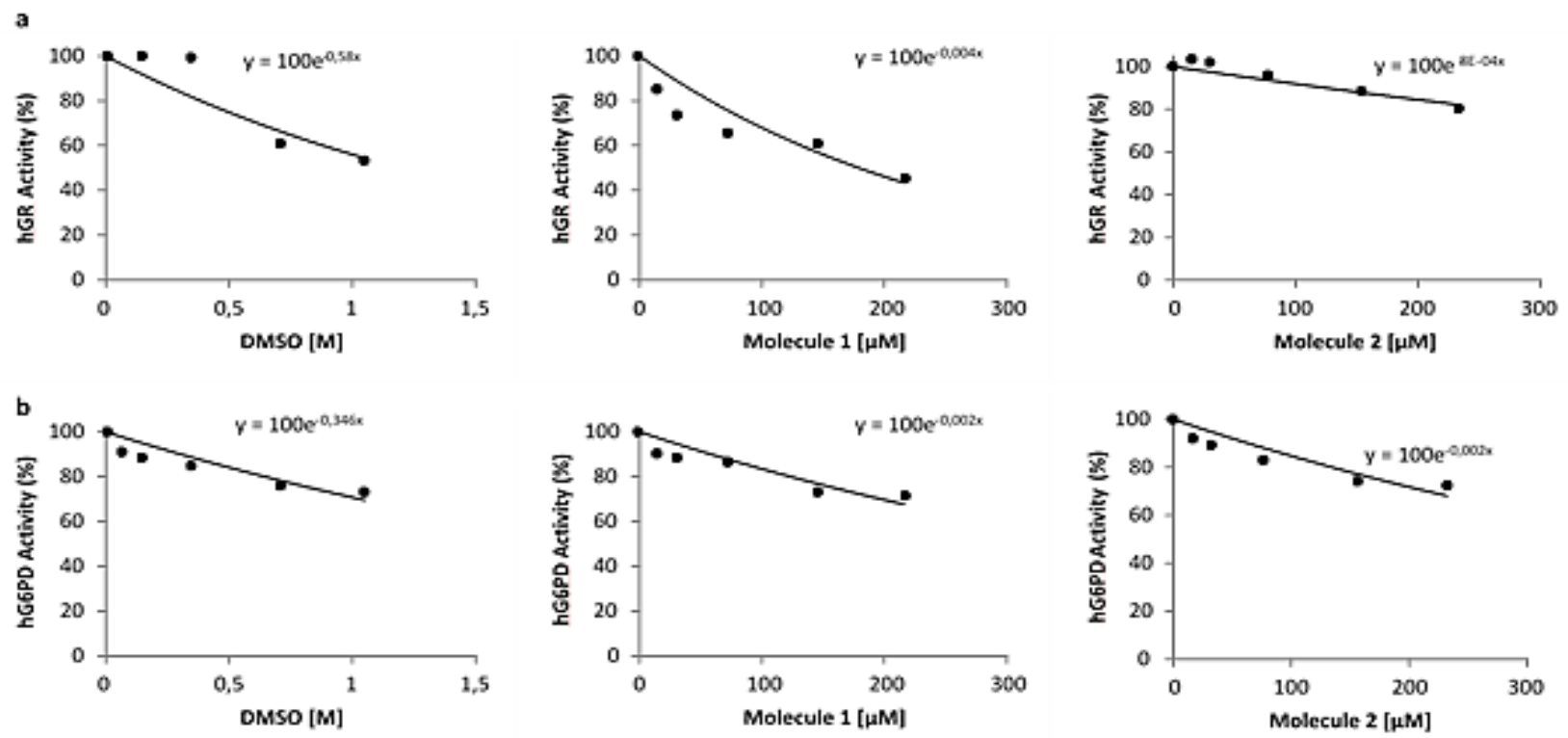

Figure 7. Activity (\%) vs. compound concentration graph for (a) hGR and (b) hG6PD enzymes in the presence of 5 different concentrations of compounds.

\subsection{Molecular Docking Studies}

We have used SiteMap toll for prediction of binding site on the hGR and hG6PD receptors and calculate active site and druggable site properties of the binding sites. Based on these calculations, we have detected that the binding sites of hGR and hG6PD receptors have high SiteScores, 1.069 and 1.033, respectively and plausible Dscores, 1.040 and 0.995 , respectively. The scores indicated that the binding sites of receptors can be accepted as active site and druggable site. These active sites of the receptors were used illustrating interactions between ligand and residues of the receptors as seen in Figure 8.

Following active site detection, we validated IFD methodology by docking co-crystallized ligand, FAD and NADP, respectively, in the detected active site of hGR and hG6PD receptors. Docking validation analyses were shown in Figure 9. When the analyses were examined in the perspective of ligand's binding position, cocrystallized and docked ligands were located in the receptors' very closet region as seen in Figure 9-a and 9-b. After docking validation, we docked compounds 1 and 2 into active sites of hGR and
hG6PD receptors and analyzed docking results on the basis of binding energies, interactions between ligand and receptor, and ligand-binding pose. Calculated binding energies of the compounds were presented in Table 4 . The binding energies have shown that the compounds have a moderate binding affinity against both hGR and hG6PD receptors. Pose with most negative binding energies was selected as best-pose of docked compounds into hGR and hG6PD receptors and interactions between best-poses of compounds and residues of receptors were analyzed. The analyses results were shown as $2 \mathrm{D}$ interaction diagram and detailed binding mode in Figure 10. Compound 1 formed hydrogen bond with Ser51 residue and $\pi$-cation with Arg291 residue of hGR receptor. The compound also formed hydrogen bond with Ser30 residue through water compound into active site of hGR receptor (Figure 10-a). Compound 2 formed $\pi$-cation with $\operatorname{Arg} 291$ residue of hGR receptor and also hydrogen bond with Gly157 and Gly158 residues through water compound into active site of hGR receptor (Figure 10-b). Compound 1 interacted through $\pi$-cation with Lys238, Lys366 and Arg370 residues and $\pi$ $\pi$ stacking with Tyr503 residue of hG6PD receptor. Moreover, the compound formed 
hydrogen bond with Tyr507 residue (Figure 10-c). Compound 2 was interacted through $\pi$-cation with Lys366 and Arg370 residues and also formed hydrogen bond with Arg487 and Gly505 residues of hG6PD receptor (Figure 10-d). The hGR and hG6PD enzymes have many important residues of active site. However, some residues in active site play important ant role catalyzing of specific reaction. Cys58, Cys63, and Tyr197 residues are some of important active sites' residues of hGR

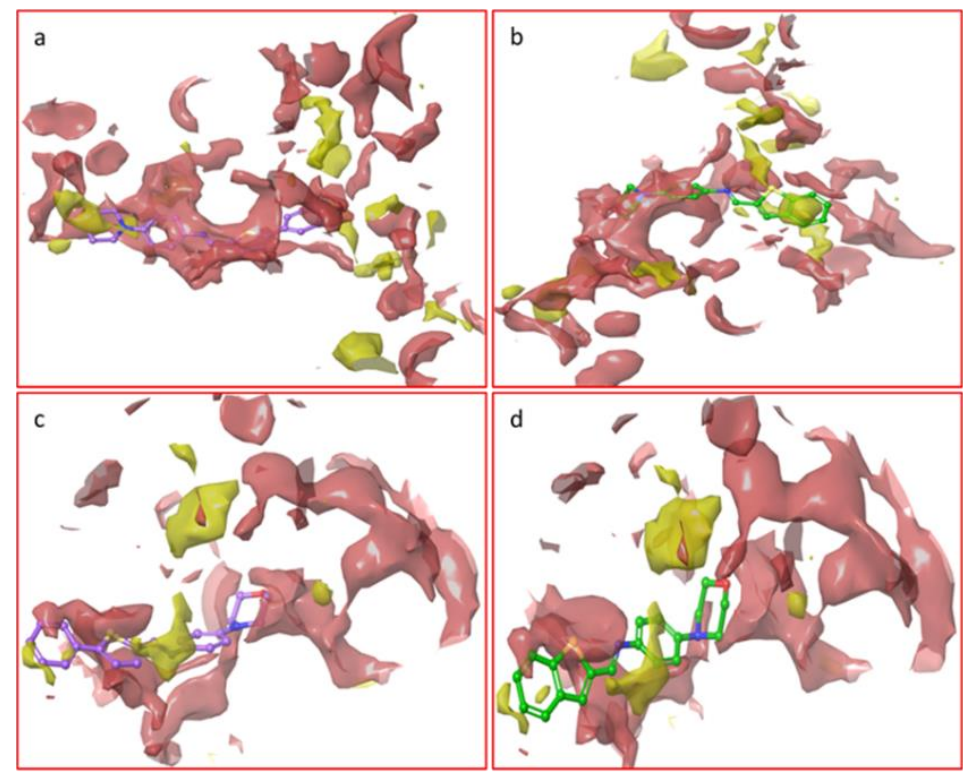

enzyme (Berkholz et al., 2008). Compound 1 and 2 did not interact closely with the residue. Lys171 and Pry 172 residues are key residues for activity of hG6PD enzyme (Hwang et al., 2018). Although compounds 1 and 2 form many $\pi$ interactions with active site residue, they do not inhibit the enzyme due to did not interact with key residues of hG6PD enzyme. Our in silico and in vitro studies results are compatible with each other.

Figure 8. Results of SiteMap analyses. (a) 1-hGR, (b) 2-hGR, (c) 1-hG6PD, and (d) 2-hG6PD. Hydrophilic site is represented as pink surface and hydrophobic site is represented as yellow surface. Compound 1 is represented in purple ball and stick modeling. Compound 2 is represented in green ball and stick modeling

Table 4. Binding energies $(\mathrm{kcal} / \mathrm{mol})$ of the compounds 1 and 2 in the catalytic active sites of hGR and hG6PD receptors.

\begin{tabular}{|c|c|c|c|c|}
\hline \multirow{2}{*}{ Compounds } & \multicolumn{2}{|c|}{ Gr } & \multicolumn{2}{c|}{ G6PD } \\
\cline { 2 - 5 } & Glide Score & IFD Score & & Glide Score \\
\hline $\mathbf{1}$ & -8.317 & -906.644 & $\mathbf{1}$ & -8.317 \\
\hline $\mathbf{2}$ & -8.823 & -961.702 & $\mathbf{2}$ & -8.823 \\
\hline
\end{tabular}
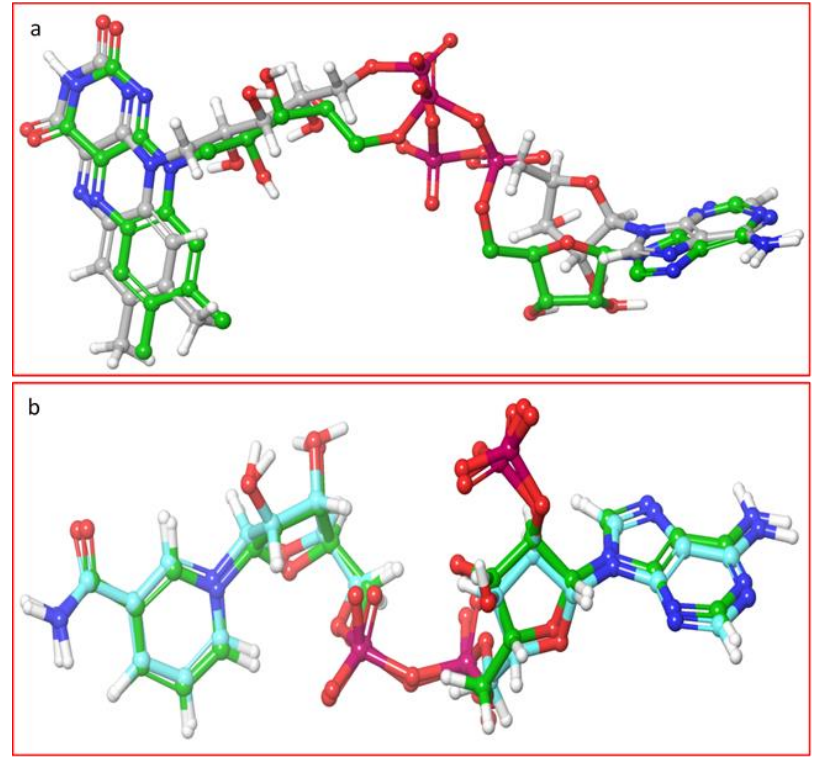

Figure 9. Docking validation analyses. (a) NADP and (b) FAD. The poses of co-crystallized ligands are represented in green color ball and stick modelling, re-docked NADP is represented in grey color ball and stick modelling and redocked FAD is represented in gyan color ball and stick modelling. 

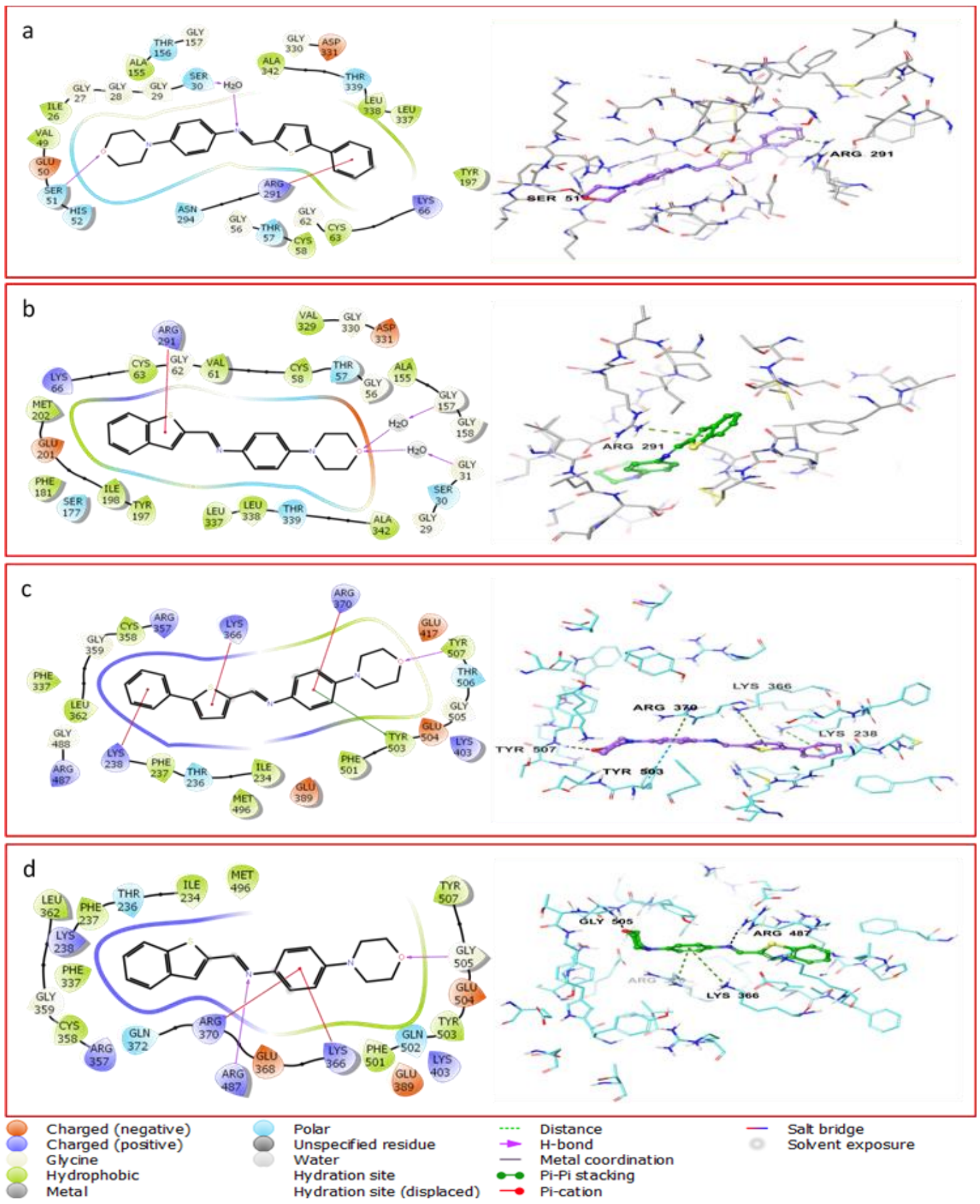

Figure 10. 2D interaction diagram and 3D detailed binding mode of compound 1 and 2 into active sites of the receptors. (a) 1-hGR, (b) 2-hGR, (c) 1-hG6PD, and (d) 2-hG6PD. Residues of hGR are depicted in grey thick tube modeling. Residues of hG6PD are depicted in gyan thick tube modeling. Compound 1 is represented in purple ball and stick modeling. Compound 2 is represented in green ball and stick modeling.

\section{Conclusion}

In this study, two new Schiff base with morpholine derivatives were synthesized. The structures of the compounds were confirmed by ${ }^{1} \mathrm{H}-\mathrm{NMR},{ }^{13} \mathrm{C}-\mathrm{NMR}$ and infrared spectrometry and their antioxidant, antibacterial, antileishmanial and enzyme activities were tested. The antioxidant activities observed from compounds 1 and 2 were remarkably high. The compounds did not have antileishmanial activity. The synthesized compounds had different rates of antibacterial activity against nine different standard bacterial isolates. We purified GR and 
G6PD enzyme human erythrocyte with affinity chromatography. Effect of synthesized compounds on the enzymes was examined with in silico and in vitro studies. According to these studies result, the enzymes that play an important role in preventing oxidative stress and maintaining of many metabolic pathways did not inhibit by the compounds which have antibacterial activity. We expect that the molecules will not cause any side effects when used as a drug.

\section{Acknowledgement}

This study was financed by Kilis 7 Aralik University (Project No: 11471/174MAP7 and 12432LTP)

\section{References}

Aridoss, G., Balasubramanian, S., Parthiban, P. and Kabilan, S. 2007. Synthesis, Stereochemistry and Antimicrobial Evaluation of Some Nmorpholinoacetyl-2,6-diarylpiperidin-4-ones.

European Journal of Medicinal Chemistry, 42, 851-860.

Bayrak, Ç., Taslimi, P., Karaman, H.S., Gülçin, I. and Menzek, A., 2019. The First Synthesis, Carbonic Anhydrase Inhibition And Anticholinergic Activities of Some Bromophenol Derivatives with $\mathrm{S}$ Including Natural Products. Bioorganic Chemistry, 85, 128-139.

Benzie, I.F.F. and Szeto, Y.T., 1999. Total Antioxidant Capacity of Teas by the Ferric Reducing/Antioxidant Power Assay. Journal of Agriculture and Food Chemistry, 47, 633-636.

Berg, J.M., Tymoczko, J.L. and Stryer, L., 2002. Glucose 6-Phosphate Dehydrogenase Plays a Key Role in Protection Against Reactive Oxygen Species: New York, W.H Freeman and Company, 1515 p.

Berkholz, D.S., Faber, H.R., Savvides, S.N. and Karplus, P.A., 2008. Catalytic Cycle of Human Glutathione Reductase Near $1 \AA$ Resolution. Journal of Molecular Biology, 382, 371-374.

Berrade, L., Aisa, B., Ramirez, M.J., Galiano, S., Guccione, S., Moltzau, L.R., Levy, F.O., Nicoletti, F., Battaglia, G., Molinaro, G., Aldana, I., Monge, A. and Perez-Silanes, S., 2011. Novel Benzo[B]Thiophene Derivatives as New Potential Antidepressants with Rapid Onset of Action. Journal of Medicinal Chemistry, 54, 3086-3090.

Beutler, E., 1975. Red Cell Metabolism. A Manual of Biochemical Methods: New York, Grune \& Stratton, $160 \mathrm{p}$.
Bradford, M.M., 1976. A Rapid and Sensitive Method for The Quantitation of Microgram Quantities of Protein Utilizing The Principle of ProteinDye Binding. Analytical Biochemistry, 72(1-2), 248-254.

Bryant, H.U. and Dere, W.H., 1998. Selective Estrogen Receptor Modulators: An Alternative to Hormone Replacement Therapy. Proceedings of the Society for Experimental Biology and Medicine, 217, 45-52.

Carlberg, I. and Mannervik, B., 1981. Purification and Characterization of Glutathione Reductase from Calf Liver. An Improved Procedure for Affinity Chromatography on 2', 5'-ADP-Sepharose 4B. Analytical Biochemistry, 116(2), 531-536.

Da Silva, C.M., da Silva, D.L., Modolob, L.V., Alves, R.B., de Resende, M.A., Martins, C.V.B. and de Fátima, Â., 2011. Schiff bases: A Short Review of Their Antimicrobial Activities. Journal of Advanced Research, 2, 1-8.

Erat, M., Sakiroğlu, H. and Ciftçi, M., 2005. Effects of Some Antibiotics on Glutathione Reductase Activities from Human Erythrocytes in Vitro and from Rat Erythrocytes in Vivo. Journal of Enzyme Inhibition and Medicinal Chemistry, 20(1), 69-74.

Helal, M.H.M., Salem, M.A., El-Gaby, M.S.A. and Aljahdali, M., 2013. Synthesis and Biological Evaluation of Some Novel Thiazole Compounds as Potential Anti-Inflammatory Agents. European Journal of Medicinal Chemistry, 13(65), 517-526.

Hwang, S., Mruk, K., Rahighi, S., Raub, A.G., Chen, C., Dorn, L.E., Horikoshi, N., Wakatsuki, S., Chen, J.K. and Mochly-Rosen, D., 2018. Correcting Glucose-6-Phosphate Dehydrogenase Deficiency with A SmallMolecule Activator. Nature Communications, 9, 4045 .

İskeleli, N.O., Alpaslan, Y.B., Direkel, Ş., Ertürk, A.G., Süleymanoğlu, N. and Ustabaş, R., 2015. The New Schiff Base 4-[(4-Hydroxy-3-fluoro5-methoxy-benzylidene)amino]-1,5-dimethyl-2phenyl-1,2-dihydro-pyrazol-3-one:

Experimental, DFT Calculational Studies and in Vitro Antimicrobial Activity. Spectrochimica Acta Part A: Molecular and Biomolecular Spectroscopy, 139, 356-366.

Jagtap, V.A.and Agasimundin, Y.S., 2015. Synthesis and Preliminary Evaluation of Some 2-aminon'-[substituted]-4,5,6,7- tetrahydro-1benzothiophene-3-carbohydrazide as Antimicrobial Agents. Journal of Pharmacy Research, 9, 10-14. 
Jiang, J.J., Chang, T.C., Hsu, W.L., Hwang, J.M., and Hsu, L.Y., 2003. Synthesis and Biological Activity of Sulfur-Containing Aryl-aldehyde Schiff Bases. Chemical Pharmaceutical Bulletin, 51, 1307-1310.

Karaman, M., Akkemik, E., Budak, H. and Ciftci, M., 2012. In Vitro Effects of Some Drugs on Human Erythrocyte Glutathione Reductase. Journal of Enzyme Inhibition and Medicinal Chemistry, 27(1), 18-23.

Kartal, N., Sokmen, M., Tepe, M., Daferera, D., Polissiou, M. and Sökmen, A., 2007. Investigation of the Antioxidant Properties of Ferula Orientalis L. Using a Suitable Extraction Procedure. Food Chemistry, 100, 584-589.

Kulandasamy, R., Adhiraki, A.V. and Stables, J.P., 2009. A New Class of Anticonvulsants Possessing $6 \mathrm{~Hz}$ activity: 3,4-Dialkyloxy Thiophene Bishydrazones. European Journal of Medicinal Chemistry, 44, 4376-4384.

Kumari, S., Badana, A.K., Mohan, M.G., Shailender G. and Malla, R.R., 2018. Reactive Oxygen Species: A Key Constituent in Cancer Survival. Biomarker Insights, 13, 1-9.

Mikus, J. and Steverding, D., 2000. A Simple Colorimetric Method to Screen Drug Cytotoxicity Against Leishmania Using the Dye

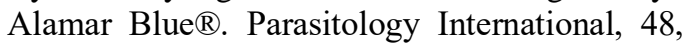
265-269.

Ninfali, P., Orsenigo, I., Barociani, L. and Rapa S.,1990. Rapid Purification of Glucose-6Phosphate Dehydrogenase from Mammal's Erythrocytes. Preparative Biochemistry, 20, 297-309.
Süleymanoğlu, N., Ünver, Y., Ustabaş, R., Direkel, Ş. and Alpaslan, G., 2017. Antileishmanial Activity Study and Theoretical Calculations for 4-Amino-1,2,4-Triazole Derivatives. Journal of Molecular Structure, 1144, 80-86.

Turkan, F., Cetin, A. Taslimi, P. Karaman, M. and Gulçin, İ., 2019. Synthesis, Biological Evaluation and Molecular Docking of Novel Pyrazole Derivatives as Potent Carbonic Anhydrase and Acetylcholinesterase Inhibitors. Bioorganic Chemistry, 86, 420-427.

Turkan, F., Cetin, A. Taslimi, P. Karaman, M. and Gulçin, İ., 2019. Synthesis, Biological Evaluation and Molecular Docking of Novel Pyrazole Derivatives as Potent Carbonic Anhydrase and Acetylcholinesterase Inhibitors. Bioorganic Chemistry, 86, 420-427.

Ünver, Y., Sancak, K., Çelik, F., Birinci, E., Küçük, M., Soylu, S. and Burnaz, N.A., 2014. New Thiophene-1,2,4-triazole-5(3)-ones: Highly Bioactive Thiosemicarbazides, Structures of Schiff Bases and Triazole-thiols. European Journal of Medicinal Chemistry, 84, 639-650.

Ünver, Y., Bektaş, E. and Direkel, Ş., 2018. Synthesis and Antioxidant and Antileishmanial Activities of New Bis N-Amino Triazole Derivatives. Russian Journal of General Chemistry, 88, 2616-2620.

Ünver, Y., Deniz, S., Çelik, F., Akar, Z., Küçük, M. and Sancak, K., 2016. Synthesis of New 1,2,4Triazole Compounds Containing Schiff and Mannich Bases (Morpholine) with Antioxidant and Antimicrobial Activities. Journal of Enzyme Inhibition and Medicinal Chemistry, 31, 89-95. 